Corporate Risk around the World

Stijn Claessens

Simeon Djankov

Tatiana Nenova
Corporate financing patterns around the world reflect countries institutional environments.
The World Bank

Financial Sector Vice Presidency

Financial Sector Strategy and Policy Group January 2000 
Policy Research Working Paper 2271

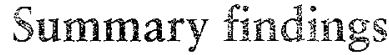

Weaknesses in the corporate sector have increasingly been cited as important factors in financial crises in both emerging markets and industrial countries. Analysts have pointed to weak corporate performance and risky financing patterns as major causes of the East Asian financial crisis. And some have argued that company balance sheet problems may also have played a role, independent of macroeconomic or other weaknesses, including poor corporate sector performance. But little is known about the empirical importance of firm financing choices in predicting and explaining financial instability.

Firm financing patterns have long been studied by the corporate finance literature. Financing patterns have traditionally been analyzed in the Modigliani-Miller framework, expanded to incorporate taxes and bankruptcy costs. More recently, asymmetric information issues have drawn attention to agency costs and their impact on firm financing choices. There is also an important literature relating financing patterns to firm performance and governance.

Several recent studies have focused on identifying systematic cross-country differences in firm financing patterns - and the effects of these differences on financial sector development and economic growth. They have also examined the causes of different financing patterns, particularly countries' legal and institutional environments.

The literature has devoted little attention to corporate sector risk characteristics, however, aside from leverage and debt maturity considerations. Even these measures have been the subject of few empirical investigations, mainly because of a paucity of data on corporate sectors around the world.

Building on data that have recently become available, Claessens, Djankov, and Nenova try to fill this gap in the literature and shed light on the risk characteristics of corporate sectors around the world. They investigate how corporate sectors' financial and operating structures relate to the institutional environment in which they operate, using data for more than 11,000 firms in 46 countries. They show that:

- The origins of a country's laws, the strength of its equity and creditor rights, and the nature of its financial system can account for the degree of corporate risktaking.

- In particular, corporations in common law countries and market-based financial systems have less risky financing patterns.

- Stronger protection of equity and creditor rights is also associated with less financial risk.

This paper - a product of the Financial Sector Strategy and Policy Group, Financial Sector Vice Presidency - is part of a larger effort in the Bank to study the determinants of the riskiness of countries' corporate and financial systems. Copies of the paper are available free from the World Bank, $1818 \mathrm{H}$ Street, NW, Washington, DC 20433. Please contact Rose Vo, room MC9-624, telephone 202-473-3722, fax 202-522-2031, email address hvo1@worldbank.org. Policy Research Working Papers are also posted on the Web at www.worldbank.org/research/workingpapers. The authors may be contacted at cclaessens@worldbank.org, sdjankov@worldbank.org, or tnenova@worldbank.org.January 2000. (52 pages)

The Policy Research Working Paper Series disseminates the findings of work in progress to encourage the exchange of ideas about development issues. An objective of the series is to get the findings out quickly, even if the presentations are less than fully polished. The papers carry the names of the authors and should be cited accordingly. The findings, interpretations, and conciusions expressed in this paper are entirely those of the authors. They do not necessarily represent the view of the World Bank, its Executive Directors, or the countries they represent. 


\title{
Corporate Risk around the World
}

\author{
Stijn Claessens
}

Simeon Djankov

Tatiana Nenova ${ }^{1}$ 


\section{Introduction}

Firm financing patterns have long been the object of study of the corporate finance literature. Financing patterns have traditionally been analyzed in the Modigliani-Miller framework, expanded to incorporate taxes and bankruptcy costs. More recently, asymmetric information issues have drawn attention to agency costs and their impact on firm financing choices. An important literature also exists relating financing patterns to firm performance and governance.

The financial structure of the corporate sector has proven relevant in some other areas of economic research. Several recent studies have focused on identifying systematic cross-country differences in firm financing patterns. Those studies have identified the effects of such differences on financial sector development and economic growth. They have also examined the causes for different financing patterns, and in particular countries' legal and institutional environments. ${ }^{2}$ Finally, firm financing choices have emerged as an important factor in the literature on predicting and explaining financial instability. ${ }^{3}$

Corporate sector risk characteristics have, however, not been much examined in the literature, aside from leverage and debt maturity considerations. Even these measures have been the object of few empirical investigations, mainly due to a paucity of data on corporate sectors around the world. Building on data which have recently become available, we fill this gap in the literature and shed light on the risk characteristics of corporate sectors around the world. We use data for 11,000 firms from 46 countries over the period 1995-96, and calculate 12 indicators typically used by financial analysts to gauge a firm's risk. We also analyze three corporate accounting profitability 
characteristics. These measures show large cross-country differences in corporate risk and performance.

We examine whether differences in corporate financing patterns and risk-taking behavior across countries reflect the legal, regulatory, and financial environments in the respective countries. We document that there are a number of institutional features which are consistently associated with the degree of financial risk-taking behavior by corporations. In particular, corporations in common law countries and those in marketbased financial systems appear less risky. Stronger protection of property rights is associated with lower measured financial risks. These institutional factors also appear to be related to cross-country profitability characteristics.

The rest of the paper is organized as follows. Section 2 discusses the related literature. Section 3 provides motivation for our work. Section 4 describes the data. Section 5 shows some simple comparisons between medians across different crosssectional characteristics of our sample. Section 6 develops the regression analysis. Section 7 concludes.

\section{Related Literature}

Our study relates to three different strands of literature. First, the corporate finance literature that investigates firms' financing patterns (including leverage and debt maturity, and other measures of company risk-taking) and the relationship between financing patterns and firm performance and governance (see Harris and Raviv 1991, for a review). The starting point for this literature has been the notion, as reflected in the Modigliani-Miller theory, that in "perfect" financial markets firm financing patterns 
should not affect firm valuation or a firm's real activities. More recent studies have drawn attention to the relationships between on the one hand the type of firm assets being financed, the risks of different types of business and the role of taxes and bankruptcy costs and on the other hand firm financing patterns. It has been established that advantageous tax benefits associated with debt financing induce higher leverage. Bankruptcy costs, on the other hand, mitigate the benefits of an all debt-financed firms, leading to an internal, optimal leverage ratio. The type of assets financed also matter. Risky types of business will be financed in ways to so as to balance the (dead-weight) costs of bankruptcy with the possible investment returns. And fixed types of investments, such as plant and equipment, will more likely be financed with long-term debt, while working capital will more likely be financed with short-term liabilities.

The analysis of agency costs and informational asymmetries has furthermore highlighted the role a firm's financial structure plays in disciplining and monitoring its management and has highlighted the impact financing patterns can have on firm valuation and behavior. This literature has made clear that financing patterns are endogenous to the firm's characteristics, including the variability of its income stream, the degree of informational asymmetries in the type of businesses the firm is engaged in, ownership structures, etc. For example, in firms with high profitability of existing operations but with limited new, profitable investment opportunities, debt financing may be a useful device to prevent managers from investing in a sub-optimal manner. And businesses which exhibit larger degree of monitoring costs may be financed with more equity to permit a larger control by owners of business activities. 
Studies so far, however, have largely analyzed these firm-specific determinants and effects of firm financing patterns in a single country context, mainly focussing on the United States. As such, this work neglects the effect of different institutional environments on financing patterns. A more recent strand of the literature, and the second research area that closely relates to this paper, is the work which compares financial structures across countries, looking for systematic differences and underlying explanatory factors. In a series of papers, Andrei Shleifer and coauthors have drawn attention to the impact of corporate governance frameworks and legal environments on (aggregate and firm-specific) financial structures and corporate sector performance. They have found that financial markets are less well-developed, equity markets are used less frequently by firms to raise funds, and dividend pay-out policies are less generous when creditor and equity rights are less well-protected, thus suggesting relationships between financial structures at the aggregate level and countries' legal characteristics. La Porta et al. (1998), for example, show that common law countries-Anglo-Saxon countries and their ex-colonies-which have stronger protection of creditor and equity rights, are characterized by more developed equity and other capital markets, and higher firm valuation than civil law countries-essentially continental European countries and their ex-colonies. Cross-country comparisons of aggregate financial structures have been made by Ross Levine and his co-authors (see, for example, Demirgüç-Kunt and Levine, 1996). Papers using firm-specific data include Rajan and Zingales (1995 and 1998), and La Porta et al. (1999a and 1999b). The last two papers relate agency problems and dividend policies around the world and the expropriation of minority shareholders arising 
from the separation of ownership and control to the strength of countries' equity and creditor rights.

In addition to comparing financing patterns across countries, some papers have investigated the impact of different corporate financing patterns on economic growth. Demirgüç-Kunt and Maksimovic (1998), for example, find that the degree to which specific firms (or the corporate sector in general) use long-term external financing from either stock markets or banks affects their growth. Levine and Zervos (1998) stress the complementarity between banks and stock markets in facilitating economic growth. Stulz (1999) reviews these and other papers on the relationships between financial structures and economic growth.

The third strand of economic literature that bears relevance to this paper is the evolving theory and empirical evidence on financial crises in emerging markets and developed countries. Two different waves ("generations") can be distinguished in this literature: those papers focussed on fundamental weaknesses, whether related to macroeconomic policies, existence of moral hazard in the financial sectors, or weak institutional frameworks, ${ }^{4}$ and those pursuing the possibility of unstable (international) financial markets. ${ }^{5}$ In this context, weaknesses in the corporate sector have been mentioned as important factors for either view. Corsetti et al. (1998), for example, mention weak corporate performance and risky financing patterns as important causal factors for the East Asian financial crisis. Krugman (1999) argues that company balance sheet problems may have a role in causing the East Asian financial crisis, independently of macro-economic or other weaknesses, including a poor performance of the corporate sector itself. In particular, Krugman suggests that a depreciation of the currency causes 
an increase in the domestic currency value of foreign-denominated firm debt. The resulting balance sheet problems (and reversal of capital flows) weaken the corporate sector, and in turn the financial system. This triggers a further currency depreciation with a current account surplus to accommodate the capital reversal and financial system weakness. Krugman ascertains that the risks of such an event occurring are higher when there is low profitability of firms relative to the cost of funds of financial institutions.

As mentioned above, empirical tests which include the role of the corporate sector in explaining financial crises are few so far. ${ }^{6}$ Johnson et al. (1998) identify a channel where a weak corporate governance framework results in more stealing by managers at the optimum, which in turn leads to large currency depreciation and recessions in the economy. The stealing occurs in part through excessive leveraging of the firm. They show empirical support for their model in a sample of 25 developing countries.

In this paper, we investigate the relationships between countries' regulatory and legal environment and firm financing characteristics, focusing on individual firms' degree of risk-taking, but also including some performance measures. As noted, recent papers highlight that institutional factors in a particular country are likely to greatly influence the performance and financing patterns of firms, including their risk-taking behavior. The body of available knowledge on financial crises further suggests that a detailed study of the impact of legal frameworks and other institutional characteristics on corporate risk-taking may have implications for the vulnerability of countries to financial crises, as well as be of interest for other reasons. So far, however, these studies have mainly concentrated on the degree to which firms use external financing and a few, selected aspects of firm financing patterns which may constitute risks (such as firm 
leverage and the degree of short-term debt). Some of these studies have also used a limited sample of countries (Rajan and Zingales, 1995, for example, focus on only seven developed countries).

We extend the literature in several directions. We use a large sample of countries and corporations to allow for broader cross-country comparisons as to the role of institutional factors. And we explore the relationships between various institutional factors - a country's legal origin, the regulatory and legal protection provided to creditors and equity holders respectively, and the market- or bank-based characterization of the country-and the financial and operating risks taken by firms in that country. We further use a large set of risk measures to ensure complete and robust results.

\section{Hypotheses}

A sizeable literature started by La Porta et al. introduces country legal characteristics as determinants of the functioning of the financial and corporate sectors of the economy. Specifically, La Porta et al. (1997) divide countries into those with civil and common law origin. ${ }^{7}$ They find that common law origin countries are characterized by higher efficiency of contract enforcement. Common law countries are also documented to offer stronger legal protection of outside investors' rights, for both shareholders and creditors. The process by which the system arrives at a legal decision is also more predictable in common law origin countries. Namely, common law systems can react faster to new developments, including those in the financial sector, and convey much less uncertainty as to the outcome of a given legal dispute resolution. This may be a result of the manner in which legal decisions are arrived at in the different systems. 
The legal process in civil law countries is based to a larger extent on the code of the law, whereas in the common law system precedents are much more important. Thus, there are large differences in judicial systems between common and civil law countries which might affect firms' risk-taking patterns.

The Modigliani-Miller framework provides a convenient approach to thinking about a relationship between the countries' institutional and legal environment and company financing and risk choices. Using this framework, one could envision that worse protection of investor rights imposes a cost on corporate claim-holders, thus increasing their required return on investment. Thus in countries with better property rights investors will be better able to limit risk-taking by corporations than in countries where investors are not sufficiently protected. The value of creditors' and equity-holders' claims depends importantly on the degree of risk-taking by the corporations. When claim-holders have stronger legal tools at their disposal, both creditors and shareholders will be able to mitigate the degree of risk-taking by managers to protect the value of their claims. ${ }^{8}$ The effect on profitability, on the other hand, is much more direct - better protection of investor rights will immediately translate into more discipline on company management. In other words, our first hypothesis is that civil law countries have higher overall risk than common law countries. This will reflect in more unstable cash flows, higher variability of the income stream in response to sales shocks, higher financial leverage, a mismatch between the maturity structure of assets and liabilities, low liquidity, and insufficient interest coverage. Corporations in civil law countries will also display lower profitability measures than those in common law countries. 
Looking at the effects of creditor and shareholder rights on overall risk, we can hypothesize, by the above arguments, a negative partial relationship between risk and protection of the rights of both claim-holder groups. While overall risk is unambiguously negatively affected by stronger rights protection, debt levels determination is more complex due to considerations of risk transfer between the two groups of claim-holders. A proper analysis of this relationship requires an explicit theoretical framework and is not pursued here.

It is important to note that risk-sharing mechanisms can differ across countries. This may be a problem since it allows for the possibility of a particular economic group bearing excessive risk, even if overall risk in the economic system is not that high. For example, firms may have high leverage, even with high income variability in response to weak disciplining by creditors, which in turn may reflect the existence of implicit or explicit government guarantees. Or, more generally, firms with high leverage and high income variability may be able to share risks in alternative ways, including creditor forbearance, reduction in wages and employment and sacrifices from suppliers. These risk-sharing mechanisms, while perhaps individually optimal, may or may not be socially optimal. Excessive risk-sharing with banks, for example, could increase the chance of a systemic crisis. It is therefore useful to consider several measures of risks.

We also explore the difference between market-based and bank-based (or relationship-based) financial systems, in part as that distinction relates to firm financing patterns, the nature of risk-sharing and the strength of outside investors' rights. Almost by definition, bank-based systems will be characterized by higher leverage as debt financing is used more extensively. The distinction also relates to the nature of corporate 
sector risk-taking and the degree of implicit versus explicit risk-sharing (see further Allen and Gale (1999) and Stulz (1999)). Allen and Gale (1994) highlight that in bank-based systems a lot of non-diversifiable risk is inter-temporally smoothed through close relationships between banks and corporations. In an arm's length environment, risksharing happens more directly through markets and is more of an intra-temporal, crosssectional nature (through price and other adjustments). While the operational risks of firms need not be different between the two systems, measures of financial risk (such as leverage) could be quite different as the forms of risk-sharing are different. Bank-based systems may thus exhibit higher measures of contemporaneous financial risk-taking, whereas in market-based systems risk measures may be lower as risk-taking is directly disciplined through the required rate of return by the market. The distinction might be further accentuated when financial intermediaries have access to a government supplied (and subsidized) safety net, which allows and induces them to take on more corporate risks.

The distinction also relates to the strength of legal rights. Banks can more easily overcome informational asymmetries than markets can and relationship-based systems may therefore function better than arm's length systems in more opaque, legally less efficient environments with large informational asymmetries. As Rajan and Zingales (1999) emphasize, bank-based systems-with greater use of debt and concurrent higher measures of financial risks-are more likely to emerge in environments with lessdeveloped property rights, laws, and institutions, with bank-firm relationships in effect serving as substitutes for weak market structures. ${ }^{9}$ This would mean that corporations in systems with weaker property rights exhibit riskier financing patterns than those in 
systems with stronger rights. It is worth to investigate whether the bank-based versus market-based distinction has an independent influence on corporate risk-taking, over and above that of the legal framework of the country. Thus our final hypothesis is that corporations in bank-based financial systems have higher debt and overall higher measures of corporate risk; however, the relationship could possibly be indirect with the legal system being a common causal factor.

We explore a multitude of measures of firm financial risk, in addition to the commonly-used leverage and maturity structure of debt measures. We do so since there exist different sources of risks and since not all risk-measures need to go in the same direction. Much of a firm's risk arises from the variability of its income. These risks are not captured by leverage and maturity structure of debt measures, but rather by the relative variation of income or sales over time. Financial measures such as leverage, in contrast, capture only the exposure of firms to financial shocks, such as changes in exchange rates or shocks to the supply of funds, and do not control for the operational risks of the firm. Measures such as the ability of a firm to cover interest payment from its operational income try to cover both financial and operational risks, but provide again a partial picture since the focus is on flow rather than stock measures of risks.

\section{Data}

We collect data from Worldscope, a database which has been used in a number of recent papers. Worldscope covers publicly-listed corporations in 54 countries. The sample we use includes all companies except financial firms (SIC codes 6000-6999) and regulated utilities (SIC codes 4900-4999). We use a balanced sample of firms over the period 1995-1996, with the exception of five ratios that are computed over the period 
1991-1996, since their calculation requires a longer time series. ${ }^{10}$. We exclude 8 countries that have less than 10 firms with non-missing data for both years (Egypt, Jordan, Liechtenstein, Luxembourg, Morocco, Russian Federation, Slovakia and Zimbabwe). We are left with 11,033 firms in 46 countries.

Table 1 presents the sample countries and shows the number of firms per country. The mean number of firms per country is 240 and the median 94 . The lowest number of firms per country is 11 for Venezuela, and the maximum number is 2715 for the US. The data cover mainly large firms. This selection pattern arises since firms have to be listed on a stock exchange in order to enter the database, and listed companies tend to be among the largest firms in each country. Previous work for nine East Asian countries (Claessens et al., 2000) suggests that the Worldscope sample covers between $64 \%$ and $96 \%$ of the total market capitalization of firms listed on the stock market. We expect that this to be the case for this larger sample of countries as well, especially for the developed countries where reporting is generally better.

The table also provides the classification of countries along different dimensions (for detailed definitions, see Table 2). We use information from La Porta et al. (1998) on legal origin to classify countries as common or civil law origin countries, with the latter further classified as French, German, or Scandinavian. Using the same primary sources, we expand on their sample of legal origin by classifying China, the Czech Republic, Hungary, and Poland as Germanic, civil law countries. We end up with 14 common law countries and 32 civil law counties, of which 18 French, 10 Germanic, and 4 Scandinavian civil law countries. 
We also report the strength of shareholder and creditor rights from La Porta et al. (1998). The shareholder index is an average of five 0-1 indicators: the country allows shareholders to mail their proxy vote; shareholders are not required to deposit their shares prior to the General Shareholders' Meeting; cumulative voting is allowed; an oppressed minorities mechanism is in place; the minimum percentage of share capital that entitles a shareholder to call an Extraordinary Shareholders' Meeting is less than or equal to $10 \%$. The creditor index is an average of four 0-1 indicators: whether the incumbent management remains in control of the company during reorganization or bankruptcy; whether the creditor is barred by "automatic stay" from taking collection action against the debtor's assets during the bankruptcy proceedings; and whether secured creditors have the first priority of claims to the debtor's assets. We expand on these data by including these rights for the four transition economies in our sample. We do not have creditor rights data for Venezuela.

Shareholder rights strongly relate to legal origin and vary from a low of 0 for Belgium to a high of 5 for common law countries such as Canada, Hong Kong, India, and the United States. Creditor rights vary between 0 for several French and Germanic civil law countries (for example, China, France and the Philippines) to a high of 4 for some common law countries (for example, the United Kingdom, Pakistan and Singapore).

For the classification of countries by the relative importance of banks versus capital markets in their financial system, we use Demirguc-Kunt and Levine (1999). Using a number of indicators on the aggregate size, activity (turnover) and efficiency of a country's respective stock market and banking system, they classify countries as bank- or market-based. We expand on their classification for China and the transition economies 
in our sample. We have 26 countries in our sample which are bank-based by these criteria and 20 which are market-based. Of the 14 common law countries, only 6 are bank-based, that is most common law countries are market-based, whereas of the 32 civil law countries 20 are bank-based.

For the measures of firms' financial risks, we use a number of ratios traditionally mentioned in corporate finance textbooks (see for example, Brealey and Myers, 1998) and used by financial analysts to assess a firm's riskiness. We also study profitability indicators. Table 2 presents the definition of the 15 specific firm-specific variables we study.

We classify these firm-level variables into seven groups. The first group measures cash-flow risk: the variability of operating income (defined as the standard deviation of the change in operating income relative to mean operating income in absolute value over the period 1991-96). Corporations with a higher volatility in operating income are more susceptible to shocks, and have earnings fall below debt service requirements, resulting in financial distress.

The second group includes two operating leverage variables; the standard deviation of the change in operating income relative to the standard deviation of the change in sales; and the standard deviation of the change in earnings after income and taxes (EBIT) relative to the standard deviation of the change in sales, both over the period 1991-96. A higher sensitivity of operational income to sales can contribute to risk if external financial markets do not allow a perfect smoothing of cash-flow variations, which in turn may cause financial and operational distress. This imperfect smoothing may be due to 
financial markets imperfections and informational asymmetries, which can be more important in weaker institutional environments.

The third group covers three financial leverage variables: the ratio of total debt to the sum of total debt and the book (market) value of equity; and the ratio of long-term debt to the sum of long-term debt and equity. High financial leverage, and associated large interest payments, will reduce the ability of a corporation to deal with financial shocks, especially interest rate increases and reductions in available financing.

The fourth group covers three liquidity measures: the current ratio, defined as the ratio of current assets (cash, inventory, other working capital and trade receivables) to current liabilities (short-term debt and trade payables); the quick ratio, defined as the ratio of current assets net of inventory to current liabilities; and a measure of the usage of short-term financing, defined as the ratio of net working capital (current assets minus current liabilities) to total assets. These ratios try to capture the corporation's ability to turn assets and earnings into liquidity quickly, which can be especially important if the company has relatively large amounts of short term debt. Financial market imperfections can contribute to the inability of a corporation to transfer (some of) its assets quickly into cash, which, if faced at the same time with large amounts of debt service payments falling. due, can cause financial distress. The current ratio captures the magnitude of assets that the company can transform into cash within a short period of time relative to what it owes in the short-term. The quick ratio recognizes that among current assets, inventories are the least liquid, and compares only the most liquid short-term assets to all short-term liabilities. Finally, net working capital to total assets measures the short-fall between current assets and current liabilities relative to total assets. 
The fifth group includes one solvency measure: the interest coverage ratio, defined as the ratio of EBIT over interest expenses. This interest coverage ratio is a standard measure of credit risk - the higher cash flows are relative to interest payments for debt service, the less likely the company is at risk of default on its debt service.

The sixth group includes two measures of debt maturity structure: the relative use of short-term debt, defined as the ratio of short-term debt to long-term debt; and the ratio of short-term debt to working capital, indicating the use of short-term debt to finance different types of assets. The ratio of short-term debt to long term debt provides a measure of roll-over risks and risks of short-term liquidity crunches. The ratio of shortterm debt to working capital tries to capture the risk of the firm running into financial distress when it can not liquidate some of its investments. This risk is exacerbated in bad economic times, since lenders would be more concerned with collecting their loans, and would be less willing to roll over debt.

Lastly, we have three profitability measures: the net income margin, defined as the ratio of net-income before preferred dividends to sales; the rate of return on equity, defined as the ratio of earnings before interest but after taxes relative to the book value of common equity; and the rate of return on assets, defined as the ratio of earnings before interest but after taxes relative to total assets, with all ratios averaged for 1995-96. The latter two are deflated with the average annual GDP deflator (obtained from the IMF's IFS), to obtain profitability measures in real terms. The three profitability measures are not influenced directly by financing patterns of the firm as they exclude interest payments. The net income margin is not influenced by inflation. 


\section{Results}

We start with a simple comparison of financing patterns for corporations in all countries with common law versus civil law origin. Table 3 compares the medians of our measures of firm risk and profitability, and provides z-tests for equality of the sample distributions, where we use all firms within our sample. We control for industry factors, however, on the logic that risk and performance measures of corporations differ across industries. ${ }^{11}$ To avoid differences in industrial structure across countries driving our results, we calculate medians in each industry group in each country. For these 552 medians ( 46 countries times 12 industries, with 44 missing observations), we then conduct z-tests. This procedure controls for differences in sample sizes across countries. It avoids putting more weight on countries with a larger number of observations, e.g. the United States and Japan. The table also presents the medians of these variables for the civil law origin countries broken down into French, German, and Scandinavian.

The comparison shows that firms in civil law countries generally display more risky financing patterns and have lower rates of return on assets and equity. Many differences are statistically significant, with $\mathrm{p}$-values generally less than $1 \%{ }^{12}$ Specifically, corporations in civil law countries have higher cash-flow variability and financial leverage ratios, lower interest cover ratios and use to a greater degree short-term debt to finance their operations. These differences are statistically significant. Civil law companies also have higher operating leverage and maintain higher liquidity, but the differences lack statistical significance. Corporations in civil law countries also exhibit statistically significant lower profitability on all three measures. The latter finding suggests that there is not necessarily a tradeoff between riskiness and performance: rather 
corporations in civil law countries have both higher risk measures and lower profitability measures. Breaking the sample of corporations in civil law countries further, we find that corporations in Germanic law countries have lower profitability than corporations in other countries and seem to take on relatively high levels of risk. Corporations in Scandinavian law countries score quite high on the three profitability measures, similar to corporations in common law countries, but have higher measures of risk, to the order of one-and-a-half to two times larger than those of common law countries.

Table 4 presents all 15 risk and profitability measures, in terms of country medians (we do not report or use means to avoid large outliers influencing the results). The variation of the variables is considerable. Looking at cash flow risk (column 1), the values range from 1.4 for Brazil to 0.20 for New Zealand. In other words, the earnings of the median corporation in Brazil have a standard deviation that is almost a time and a half larger than earnings themselves. Earnings in Brazil can thus be expected to fluctuate between less than a quarter and more than four times their value with a $95 \%$ probability, assuming a normal distribution. The earnings of the median company in New Zealand, on the other hand, are expected to move by at most $60 \%$ of their value $95 \%$ of the time.

Operating leverage is also very different across countries. The sensitivity of changes in EBIT to changes in sales ranges from 1.96 in Finland to 0.30 in Austria. In other words, a $1 \%$ fall in sales from one year to the next decreases EBIT by $2 \%$ in Finland, and by only $0.2 \%$ in Austria. Operating leverage is very heavily dependent on the type of industry that the company is in, and consequently companies usually have little control over this risk factor. 
Comparing leverage across countries, we see the highest leverage in Korea, where the median company has long-term debt and total debt equal to $49 \%$ and $249 \%$ of the equity value of the company, respectively. The lowest total debt is found for South Africa ( $7.5 \%$ of equity value), and the lowest long term debt is found for Turkey $(0.2 \%$ of equity value). Liquidity is the highest in Turkey and Peru, and the lowest in Pakistan. The median Pakistani company has a current ratio of 0.99 and a quick ratio of 0.51 , which means that its current assets are only slightly smaller than its current liabilities, and half of those current assets are actually inventories, which are considered the least liquid of current assets. The median Pakistani company also has negative net working capital.

The median Malaysian company's earnings cover interest payments almost 7 times, whereas the median Korean company's interest coverage is less than one and a half. New Zealand companies have short-term debt that is only $11 \%$ of long-term liabilities. In Hungary, in contrast, short-term debt is more than five times long-term debt. Comparing short-term debt to net working capital, which proxies a measure of immediate financing needs, we find that in Pakistan the median company's short-term debt is $4 \%$ of short-term financing needs. In Sri Lanka, short-term financing needs are $43 \%$ of short-term liabilities. Turkey's companies have the highest median profitability, while Korean and Japanese companies have the lowest profitability measures.

We next compare countries by the quality of the legal protection offered to creditors. Table 5 shows medians and corresponding z-tests, when we divide the sample into corporations in countries with good creditor protection (scores of 3 and 4 on creditor rights) and those with bad protection (scores of 0,1 , and 2). The table also presents firm risk and profitability characteristics by the individual creditor protection scores from 0 to 
4. Again, we control for industry effects in the manner discussed above. The effects of creditor protection on firm risk and profitability characteristics are large, with firms in countries with less creditor protection generally displaying more risky financing patterns and lower rates of return on assets and equity. Fewer differences are statistically significant, however, compared to the distinction between civil and common law countries. Specifically, corporations in weak creditor rights countries have significantly higher cash-flow variability. Corporations in weak creditor rights countries also have significantly higher liquidity (quick ratio). In good creditor protection countries, operating and financial leverage are lower, and interest cover ratios are higher, though the differences are not significant. Corporations in weak creditor rights countries use to a significantly lesser degree short-term debt to finance their operations. Finally, corporations in weak creditor rights countries exhibit significantly lower profitability. Breaking down results by the specific creditor right index-value, we do not find any monotonic relationships.

We then divide the sample of corporations into those in countries with good minority protection (scores of 4 and 5 on anti-director rights) and those in countries with weak minority rights (scores of $0,1,2$, and 3 ). Table 6 shows the medians and z-tests for firm risk and profitability characteristics of corporations divided in these two classes, controlling for industry effects. We find that corporations in weak minority rights countries have statistically significant higher cash-flow variability. Operating leverage results do not differ. All measures of financial leverage are significantly higher for corporations in weaker minority rights countries, and those for liquidity risks are lower (although not significant). Interest coverage is significantly higher in better protection 
countries. Both measures of short-term debt are higher among corporations in weaker minority rights countries and again the difference is statistically significant. Finally, profitability appears to be significantly lower among corporations in weaker minority rights countries.

Breaking down results by the specific minority rights index-values, we do not find many monotonic relationships. For some variables, we find a $U$-shaped, for other an inverse U-shaped pattern, and for some no pattern at all. For profitability measures, for example, we find that profitability generally increases with the protection of equity rights, however, for the index value of 3 , profitability is less than for equity rights values of 2 and 4. We expect that firm-specific characteristics play a role in explaining this particular effect, but also venture that the relationship between firm financing patterns and minority rights is complex.

We next use the Demirguc-Kunt and Levine (1999) classification of countries into bank-oriented and market-oriented systems to explore the relationship of the type of financial system with firm risk and profitability characteristics (Table 7). We find that corporations in bank-oriented systems have more risky financial structures and appear less profitable. These corporations have statistically significant higher cash-flow variability and higher financial leverage. Operating leverage and liquidity measures do not differ significantly. Interest coverage is significantly lower for corporations in bankcentered countries. Corporations in those countries also use significantly more short-term debt than their counterparts in market-based economies. Finally, firms in market-based financial systems have statistically higher profitability. 
As a robustness check, we repeat all tests above on a sample excluding the G-7 countries. Since many common law countries display a high level of development, our results on legal origin could reflect development effects instead of legal framework effects. Excluding the G-7 does not change the results substantially, except that the level of statistical significance increases slightly. All results are maintained qualitatively.

In summary, the results suggest that legal origin, the degree of creditor and minority rights protection and the characterization of the financial system are important in influencing the risk-taking behavior of corporations. Whether legal origin alone can explain corporate financing patterns has been recently countered by Rajan and Zingales (1999). They argue that legal systems are not exogenous to political and other circumstances. If a particular legal system were proven to be effective, other countries would imitate valuable regulations including equity and creditor protection, and gradually differences in legal systems would disappear. Thus any causality from legal origin to financial characteristics is disputable. We find, however, that the legal origin is at least as discriminating a factor as the degree of creditor or shareholder protection. But; since these results do not control for other firm characteristics, we need to be careful in interpretation. We next turn to regression results to investigate firm financing patterns more carefully.

\section{Regression results}

The results so far provide comparisons of median risk and profitability measures across countries without controlling for firm characteristics. As noted, the corporate finance literature has drawn attention to a number of firm-specific factors which can 
affect financing patterns (see Harris and Raviv 1991 for a review). We next report regression results using firm-specific control variables. ${ }^{13}$

We use nine variables as control variables at the firm level. Those have been used in other studies trying to explain firm financing patterns (Titman and Wessels, 1988, Demirguc-Kunt and Maksimovic, 1998 and forthcoming, Rajan and Zingales, 1995). We divide these variables into an expanded control set, used only for the leverage regressions, and a smaller control set, used for all other regressions. The smaller control set consists of four variables. The first variable is firm market value (in log-terms and expressed in US dollars to allow comparability across countries), to control for the effects of size on financing patterns. The second variable is the growth of total assets, deflated using a GDP-price index, to control for the firm-specific growth opportunities which can influence financing patterns. The third variable is the industry classification, as financing patterns can be expected to depend on the type of activity financed including the volatility of the underlying income stream, the degree of informational asymmetries in the management of the particular type of business, etc. We have the two-digit SITC groups for each firm, but this classification is too detailed for our purposes. Instead, we use Campbell (1996) to re-classify the two-digit SIC groups to 12 industry categories. ${ }^{14}$ The fourth variable is the level of GNP per capita (in log terms and expressed in dollars), to control for cross-country differences in the level of development. The latter could affect the amount of risk that the corporate sector is willing to assume. ${ }^{15}$

The expanded set of controls includes five additional firm-level characteristics. The first variable is the availability of collateral which can influence the degree to which a firm can obtain long-term financing. It is defined as the sum of inventory and gross plant 
and equipment, relative to total assets. The second variable controls for the presence of non-debt tax shields, which would influence the relative tax-advantages of debt financing vis-à-vis other sources of tax savings. It is defined as the degree of depreciation relative to total assets. The third control variable is operating income to total assets, deflated using the respective GDP-price index, to control for the profitability of the particular firm. We expect more profitable firms to have higher cash flows available, and therefore use less debt and more internal financing. To further control for the instability of the corporate cash flow stream, we include as a fourth variable the volatility of earnings, defined as the standard deviation of changes in EBIT, scaled by average EBIT. ${ }^{16}$ Finally, we control for the relative tax advantage of debt versus equity financing. The reason for a tax advantage of debt over equity financing is that an equal amount of debt and equity financing costs differ in their net of tax values, due to the different tax rates applied to interest payments as opposed to dividend payments (or capital gains). ${ }^{17}$

In all regressions, we reduce the importance of outliers in our estimates by capping observations at the $10 \%$ level (both tails). We use OLS regressions with dummies for each of the 12 industry groups in the sample. ${ }^{18}$ To simplify the amount of information presented, we use in our regressions only one measure for each of the seven groups of risk or performance measures. The results for each measure within a class are very similar, however. Table 8 provides the regression results for the financial leverage ratio, while Table 9 provides all regression results in a summary form, where we report the sign of the coefficients if they are statistically significant, positive $(+)$ or negative $(-), 0$ otherwise. ${ }^{19}$ Similarly to the z-tests, we check the results for robustness by repeating the 
regressions on a sample which excludes the G-7 countries. We obtain qualitatively identical results.

The financial leverage regressions use the total debt to book value of equity as the left-hand side variable. Civil legal origin increases leverage in a statistically and economically significant way. Both better creditor rights and shareholder rights protection have a negative and significant impact on leverage. Bank-based financial systems are characterized by lower leverage. When both the bank-based financial system indicator and the civil legal origin indicator are included in the regression as explanatory variables, the legal origin has a positive impact and the type of financial system dummy has a negative impact on leverage, both being statistically significant.

The controls are of the expected signs and are statistically significant. More collateral increases leverage, whereas the availability of alternative sources of tax savings decreases debt usage. More profitable companies have less debt, possibly because they finance themselves to a larger extent out of retained earnings. Larger companies are less leveraged, possibly because they face a relatively lower cost of equity financing. Higher asset growth is associated with higher leverage, which is consistent with higher financing needs and unconstrained credit markets, but is inconsistent with the argument that high growth companies usually have poor collateral to borrow against. The volatility of earnings is positively related to leverage. A higher tax advantage of debt over equity increases leverage, and firms in more developed countries have less debt, possibly due to the presence of more developed stock markets. The industry dummies are jointly significant in all regressions. 
In terms of legal origin, controlling for firm characteristics, the results are the same as for the simple z-test comparisons (regression I of Table 9). Corporations in civil countries have higher cash-flow variability, higher operating and financial leverage, and have lower interest coverage. They also use more short-term debt and are less profitable. Different from the z-test results, civil legal origin is significantly associated with lower liquidity. These findings correspond to those of others, most notably La Porta et al. (1998), that legal systems matter for the financing patterns of corporations.

Controlling for individual firm characteristics, the influence of creditor and antidirector rights on financing patterns is consistent with our hypotheses, and with the legal origin results mentioned above. ${ }^{20}$ Stronger creditor rights are associated with lower firm risk characteristics, in particular, lower cash-flow risk, financial leverage and liquidity, and higher interest coverage (regression II). Further, stronger creditor rights are positively related to profitability. Creditor protection is not statistically significantly associated with operating leverage, and is significantly associated with more short-term debt use. The relationship of credit rights with debt maturity lacks significance in some of the alternative measures, however. The lack of explanatory power of creditor rights for debt maturity structure has been noted elsewhere in the literature. ${ }^{21}$

The effect of shareholder rights protection after controlling for firm characteristics is similar but the results are stronger: good shareholder protection is associated with lower firm risk, in particular, cash-flow risk, operating leverage, financial leverage, and short-term debt use (regression III). Good protection is also associated with higher interest coverage, liquidity, and profitability. ${ }^{22}$ 
The results for bank- versus market based financial systems (regression IV) are that corporations in bank-based countries have higher cash flow risk, operating and financial leverage, and more short-term debt. Corporations in these countries also have lower liquidity, interest coverage, and profitability. These results confirm our priors. However, this link may not be causal; in particular, when controlling for legal origin, the statistical significance of the relationship disappears in some cases (for operating and financial leverage and for liquidity) (regression V). The relationship between legal systems and the type of financial system is complex and likely influences these results (Rajan and Zingales (1999)).

\section{Conclusions}

In this paper, we show that corporations' financial and operating structures relate to the institutional environments in which they operate. A country's legal origin, the strength of its shareholder and creditor rights, and the nature of its financial system can account for the degree of corporate risk-taking. In particular, corporations in common law countries and market-based financial systems appear less risky. Greater protection of investor rights is associated with lower measured financial risks as well. This suggests that the financing patterns of the corporate sector across countries reflect countries' institutional environments.

Our work points to the importance of constructing useful and operational measures of corporate sector risk, at the micro level, in addition to monitoring sectoral and countrywide economic risks. The risk measures we propose constitute a step towards a system for measuring such risk. Further work is necessary to formulate well-specified models 
linking firm-level risk to corporate sector stability. Those models will also help test whether there exists a connection between corporate risk-taking behavior and financial crises. A further policy implication of the paper is the importance of a country's institutional development in relation to its corporate sector stability, as well as that of the overall economy.

Research in this area needs to distinguish further between the influence of legal variables and the importance of the type of financial system. The insights gained in this study can also be utilized in future models of corporate behavior as regards the use of external financing. Finally, one important unanswered question is the exact causality or transmission mechanism that is responsible for the observed higher risk measures in civil law countries. 


\section{References}

Akerlof, George, and Paul Romer, 1993, "Looting: The Economic Underworld of
Bankruptcy for Profit," Brookings Papers on Economic Activity, 0, 2: 1-60.

Allen, Franklin, and Douglas Gale, 1995, "Welfare comparison of intermediaries and financial markets in Germany and the US," European Economic Review, 39, 2: 179-209 February. , 1999, Comparing Financial Systems, MIT Press, Cambridge, forthcoming.

Brealey, Richard and Stewart Myers, 1998, Principles of corporate finance, New York: McGraw-Hill.

Campbell, John, 1996, "Understanding Risk and Return", Journal of Political Economy, 104: 298-345.

Caprio, Gerard, and Asli Demirguc-Kunt, 1997, "The Role of Long-Term Finance: Theory and Evidence”, World Bank Policy Research Working Paper 1746.

Chang, Roberto and Andres Velasco, 1998, "Financial crises in emerging markets: a canonical model." NBER Working Paper Series 6606, June. 
Claessens, Stijn, Simeon Djankov, and Larry Lang, 2000, "The Separation of Ownership and Control in East Asian Corporations", Journal of Financial Economics, forthcoming.

Corsetti, Giancarlo, Paolo Pesenti, Nouriel Roubini, 1998, "What Causes the Asian Currency and Financial Crises? A Macroeconomic Overview," New York University, mimeo.

Demirguc-Kunt, Asli and Ross Levine, 1999, "Bank-Based and Market-Based Financial Systems: Cross-Country Comparisons", World Bank Policy Research Working Paper 2146.

Demirgüç-Kunt, Asli and Ross Levine, 1996, "Stock Markets, Corporate Finance, and Economic Growth: An Overview", World Bank Economic Review, 10:2, May, 223-39.

Demirgüç-Kunt, Asli, and Maksimovic, Vojislav, 1998, "Law, Finance, and Firm Growth", Journal of Finance, 53, 6: 2107- 37.

, "Institutions, Financial Markets, and Firm Debt", Journal of Financial Economics, (forthcoming). 
Diamond, Douglas, and Philip Dybvig, 1983, "Bank Runs, Deposit Insurance, and Liquidity," Journal of Political Economy, 91, 3: 401-419.

Edwards, Sebastian, and Julio Santaella, 1993, "Devaluation Controversies in the Developing Countries: Lessons from the Bretton Woods Era," in Bordo, Michael and Barry Eichengreen, Eds., A Retrospective on the Bretton Woods System: Lessons for International Monetary Reform, University of Chicago Press, Chicago and London.

Eichengreen, Barry, Andrew Rose, and Charles Wyplosz, 1995, "Exchange Market Mayhem: The Antecedents and Aftermath of Speculative Attacks," Economic Policy, 21: 249-296.

Harris, Milton, and Artur Raviv, 1991, "The Theory of Capital Structure," Journal of Finance, 46, 1:297-355.

Johnson, Simon, Peter Boone, Alasdair Breach, and Eric Friedman, 1998, "Corporate Governance in the Asian Financial Crisis, 1997-8", MIT, mimeo.

Krugman, Paul, 1979, “A Model of Balance-of-Payments Crises”, Journal of Money, Credit, and Banking, 11, 3:311-325. 
, 1999, "Balance Sheets, the Transfer Problem, and Financial Crises",

mimeo, MIT (on http://www.mit.edu/krugman/)

La Porta, Rafael, Florencio Lopez-de-Silanes, Andrei Shleifer, Robert Vishny, 1997, "Legal Determinants of External Finance", Journal of Finance, 52, 3: 1131-50. , 1998, "Law and Finance", Journal of Political Economy, vol. 106 (6), pp. 1113-55. , 1999a, "Agency Problems and Dividend Policies Around the World," Journal of Finance, forthcoming. , 1999b, "Investor Protection: Origins, Consequences, Reform," Harvard University, mimeo. , 1999c, "Investor Protection and Corporate Valuation," Harvard University, mimeo.

Levine, Ross, and Sara Zervos, 1998, "Stock Markets, Banks, and Economic Growth," American Economic Review, vol. 88 (June), pp. 537-558.

Obstfeld, Maurice, 1986, "Rational and Self-Fulfilling Balance-of-Payments Crises." American Economic Review, 76:72-81, March. 
Portes, Richard, 1999," "The Use and Misuse of Financial Crisis Prediction Models", Agenor, Pierre Richard, Marcus Miller, David Vines, and Axel Weber, Eds., The Asian Financial Crisis, Cambridge University Press, Cambridge.

Radelet, Steven, and Jeffrey Sachs, 1998, "The East Asian Financial Crisis: Diagnosis, Remedies, Prospects," Brookings Papers on Economic Activity, 1: 1-74.

Rajan, Raghuram, and Luigi Zingales, 1995, "What Do We Know About Capital Structure? Some Evidence From International Data", Journal of Finance, 50, 5: 1421-60. , 1998, "Financial Dependence and Growth", American Economic Review, 80, 3: 559-86. , 1999, "Which Capitalism? Lessons from the East Asian Crisis", Journal of Applied Corporate Finance, April. , 1999, "The Politics of Financial Development," University of Chicago and NBER, mimeo.

Stulz, Rene, 1999, "Financial structure, corporate finance, and economic growth," mimeo, Ohio State University 
Titman, Sheridan, and Roberto Wessels, 1988, "The Determinants of Capital Structure Choice", The Journal of Finance, 43, 1: 1-19. 
Table 1: The Sample

\begin{tabular}{|c|c|c|c|c|c|c|}
\hline \multicolumn{2}{|c|}{ Obs. country } & \multirow{2}{*}{$\begin{array}{l}\begin{array}{l}\text { sample } \\
\text { size }\end{array} \\
25\end{array}$} & \multirow{2}{*}{$\begin{array}{l}\text { legal origin } \\
\text { civil law (French) }\end{array}$} & \multirow{2}{*}{$\begin{array}{l}\text { antidirector } \\
\text { rights }\end{array}$} & \multirow{2}{*}{$\begin{array}{r}\begin{array}{l}\text { creditor } \\
\text { rights }\end{array} \\
1\end{array}$} & \multirow{2}{*}{$\begin{array}{l}\begin{array}{l}\text { bank- } \\
\text { oriented } \\
\text { system }\end{array} \\
1\end{array}$} \\
\hline 1 & ARGENTINA & & & & & \\
\hline 2 & AUSTRALIA & 189 & common law & 4 & 1 & 0 \\
\hline 3 & AUSTRIA & 57 & civil law (German) & 2 & 3 & 1 \\
\hline 4 & BELGIUM & 72 & civil law (French) & 0 & 2 & 1 \\
\hline 5 & BRAZIL & 119 & civil law (French) & 3 & 1 & 0 \\
\hline 6 & CANADA & 403 & common law & 5 & 1 & 0 \\
\hline 7 & CHILE & 48 & civil law (French) & 5 & 2 & 0 \\
\hline 8 & CHINA & 76 & civil law (German) & 1 & 0 & 1 \\
\hline 9 & COLOMBIA & 20 & civil law (French) & 3 & 0 & 1 \\
\hline 10 & CZECH REPUBLIC & 14 & civil law (German) & 2 & 2 & 1 \\
\hline 11 & DENMARK & 121 & civil law (Scandinavian) & 2 & 3 & 0 \\
\hline 12 & FINLAND & 79 & civil law (Scandinavian) & 3 & 1 & 1 \\
\hline 13 & FRANCE & 428 & civil law (French) & 3 & 0 & 1 \\
\hline 14 & GERMANY & 414 & civil law (German) & 1 & 3 & 1 \\
\hline 15 & GREECE & 94 & civil law (French) & 2 & 1 & 1 \\
\hline 16 & HONG KONG & 182 & common law & 5 & 4 & 0 \\
\hline 17 & HUNGARY & 14 & civil law (German) & 3 & 2 & 1 \\
\hline 18 & INDIA & 283 & common law & 5 & 4 & 1 \\
\hline 19 & INDONESIA & 104 & civil law (French) & 2 & 1 & 1 \\
\hline 20 & IRELAND & 46 & common law & 4 & 1 & 1 \\
\hline 21 & ISRAEL & 28 & common law & 3 & 4 & 1 \\
\hline 22 & ITALY & 125 & civil law (French) & 1 & 2 & 1 \\
\hline 23 & JAPAN & 2116 & civil law (German) & 4 & 2 & 1 \\
\hline 24 & KOREA (SOUTH) & 214 & civil law (German) & 2 & 3 & 0 \\
\hline 25 & MALAYSIA & 253 & common law & 3 & 3 & 0 \\
\hline 26 & MEXICO & 68 & civil law (French) & 1 & 0 & 0 \\
\hline 27 & NETHERLANDS & 152 & civil law (French) & 2 & 2 & 0 \\
\hline 28 & NEW ZEALAND & 37 & common law & 4 & 3 & 1 \\
\hline 29 & NORWAY & 85 & civil law (Scandinavian) & 4 & 2 & 1 \\
\hline 30 & PAKISTAN & 72 & common law & 5 & 4 & 1 \\
\hline 31 & PERU & 21 & civil law (French) & 3 & 0 & 0 \\
\hline 32 & PHILIPPINES & 64 & civil law (French) & 3 & $\mathbf{0}$ & 0 \\
\hline 33 & POLAND & 36 & civil law (German) & 3 & 2 & 1 \\
\hline 34 & PORTUGAL & 53 & civil law (French) & 3 & 1 & 1 \\
\hline 35 & SINGAPORE & 158 & common law & 4 & 4 & 0 \\
\hline 36 & SOUTH AFRICA & 139 & common law & 5 & 3 & 0 \\
\hline 37 & SPAIN & 97 & civil law (French) & 4 & 2 & 1 \\
\hline 38 & SRI LANKA & 12 & common law & 3 & 3 & 1 \\
\hline 39 & SWEDEN & 143 & civil law (Scandinavian) & 3 & 2 & 0 \\
\hline 40 & SWITZERLAND & 117 & civil law (German) & 2 & 1 & 0 \\
\hline 41 & TAIWAN & 177 & civil law (German) & 3 & 2 & 1 \\
\hline 42 & THAILAND & 190 & civil law (French) & 2 & 3 & 0 \\
\hline 43 & TURKEY & 38 & civil law (French) & 2 & 2 & 0 \\
\hline 44 & UNITED KINGDOM & 1124 & common law & 5 & 4 & 0 \\
\hline 45 & UNITED STATES & 2715 & common law & 5 & 1 & 0 \\
\hline \multirow{2}{*}{46} & VENEZUELA & 11 & civil law (French) & 1 & n.a. & 1 \\
\hline & AVERAGE & 240 & & 3.02 & 1.96 & 0.56 \\
\hline
\end{tabular}


Table 2: Firm-Level Risk Measures and Control Variables

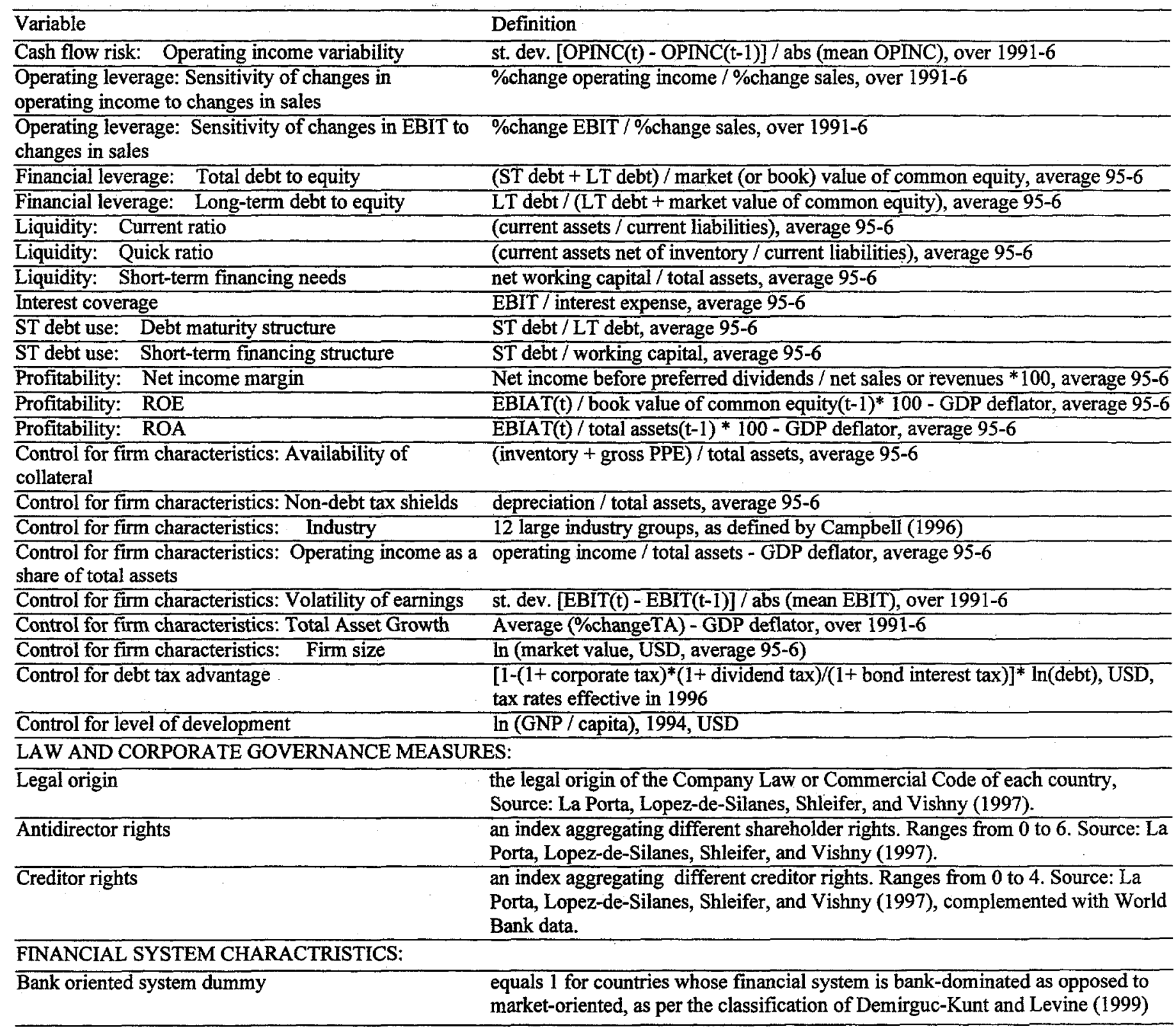


Table 3: Civil vs. Common Law Origin

\begin{tabular}{|c|c|c|c|c|c|c|c|}
\hline & Common & Civil & Z-test & & Civil by & rigin: & \\
\hline & & & & & French & German & Scandinavian \\
\hline Number of Observations & 162 & 346 & & & 191 & 105 & 50 \\
\hline $\begin{array}{l}\text { Cash flow risk: Operating income } \\
\text { variability }\end{array}$ & 0.3803 & 0.5796 & 6.8030 & a & 0.6161 & 0.4590 & 0.6124 \\
\hline $\begin{array}{l}\text { Operating leverage: Sensitivity of changes } \\
\text { in operating income to changes in sales }\end{array}$ & 1.0654 & 1.1324 & 0.8700 & & 1.0397 & 1.2296 & 1.4841 \\
\hline $\begin{array}{l}\text { Operating leverage: Sensitivity of changes } \\
\text { in EBIT to changes in sales }\end{array}$ & 1.0050 & 1.0299 & 1.0950 & & 0.9912 & 1.0299 & 1.6407 \\
\hline Financial leverage: Total debt to equity & 0.2653 & 0.4009 & 4.0850 & a & 0.4232 & 0.3846 & 0.3321 \\
\hline Financial leverage: LT debt to equity & 0.1187 & 0.1497 & 2.2600 & b & 0.1441 & 0.1490 & 0.1799 \\
\hline Liquidity: Current ratio & 1.4229 & 1.4443 & 0.4050 & & 1.4159 & 1.4778 & 1.6451 \\
\hline Liquidity: Quick ratio & 0.9915 & 1.0109 & 0.3390 & & 0.9376 & 1.0567 & 1.1008 \\
\hline Liquidity: ST financing needs & 0.1152 & 0.1360 & 0.8640 & & 0.1181 & 0.1543 & 0.1729 \\
\hline Interest cover & 5.0541 & 3.4225 & 4.4460 & a & 3.1464 & 3.4686 & 4.5938 \\
\hline ST debt use: Debt maturity structure & 0.5852 & 0.8497 & 3.7590 & $\mathbf{a}$ & 0.9095 & 1.2466 & 0.3377 \\
\hline ST debt use: ST financing structure & 0.1590 & 0.2607 & 1.5140 & & 0.2913 & 0.2486 & 0.1904 \\
\hline Profitability: Net income margin & 5.1017 & 4.0931 & 2.3440 & b & 4.7193 & 3.2195 & 4.5072 \\
\hline Profitability: ROE & 13.0454 & 10.4417 & 3.0980 & a & 10.1014 & 6.8409 & 13.4739 \\
\hline Profitability: ROA & 6.9891 & 5.9114 & 2.5760 & a & 6.6475 & 4.3066 & 6.9159 \\
\hline
\end{tabular}

Notes: The $\mathrm{z}$-tests are performed on medians.

a shows significance at the $1 \%$ level;

${ }^{b}$ shows significance at the $5 \%$ level. 
Table 4: Firm-Level Risk Measures: Country Medians

\begin{tabular}{|c|c|c|c|c|c|c|c|c|c|c|c|c|c|c|c|c|}
\hline & & CF risk & Operating le & verage & Financial le & verage & & Liquidity & & & & Short-term de & lebt use & Profitability & (in percent) & \\
\hline Country & \# obs. & $\begin{array}{l}\text { Operating } \\
\text { income } \\
\text { variability }\end{array}$ & $\begin{array}{l}\text { Sensitivity } \\
\text { of changes } \\
\text { in operating } \\
\text { income to } \\
\text { changes in } \\
\text { sales }\end{array}$ & $\begin{array}{l}\text { Sensitivity } \\
\text { of changes } \\
\text { in EBIT to } \\
\text { changes in } \\
\text { sales }\end{array}$ & $\begin{array}{l}\text { Total debt } \\
\text { to (book } \\
\text { value of) } \\
\text { equity }\end{array}$ & $\begin{array}{l}\text { Total debt } \\
\text { to (market } \\
\text { value of) } \\
\text { equity }\end{array}$ & $\begin{array}{l}\text { Long term } \\
\text { debt to } \\
\text { (market } \\
\text { value of) } \\
\text { equity }\end{array}$ & $\begin{array}{l}\text { Current } \\
\text { ratio }\end{array}$ & Quick ratio & $\begin{array}{l}\text { Net } \\
\text { working } \\
\text { capital to } \\
\text { total assets }\end{array}$ & $\begin{array}{l}\text { Interest } \\
\text { coverage }\end{array}$ & $\begin{array}{l}\text { Short term } \\
\text { debt to long } \\
\text { term debt }\end{array}$ & $\begin{array}{l}\text { Short term } \\
\text { debt to net } \\
\text { working } \\
\text { capital }\end{array}$ & $\begin{array}{l}\text { Net income } \\
\text { margin (of } \\
\text { sales) }\end{array}$ & $\begin{array}{l}\text { Return to } \\
\text { equity }\end{array}$ & $\begin{array}{l}\text { Return to } \\
\text { assets }\end{array}$ \\
\hline ARGENTINA & 25 & 0.840 & 1.999 & 1.814 & 0.356 & 0.328 & 0.094 & 1.195 & 0.747 & 0.036 & 4.279 & 0.796 & 0.448 & 8.192 & 12.354 & 8.139 \\
\hline AUSTRALIA & 189 & 0.426 & 0.994 & 0.933 & 0.339 & 0.198 & 0.122 & 1.601 & 1.033 & 0.104 & 5.480 & 0.209 & 0.116 & 5.859 & 9.916 & 6.649 \\
\hline AUSTRIA & 57 & 1.240 & 0.87 & 0.302 & 0.773 & 0.463 & 0.229 & 1.702 & 1.034 & 0.212 & 2.726 & 1.570 & 0.298 & 3.104 & 13.357 & 4.504 \\
\hline BELGIUM & 72 & 1.057 & 1.000 & 0.770 & 0.784 & 0.423 & 0.176 & 1.332 & 0.945 & 0.142 & 3.798 & 0.712 & 0.393 & 2.523 & 9.403 & 5.160 \\
\hline BRAZIL & 119 & 1.391 & 0.941 & 1.267 & 0.447 & 0.934 & 0.269 & 1.275 & 0.911 & 0.066 & 1.497 & 1.138 & 0.381 & 1.754 & 3.979 & 4.229 \\
\hline CANADA & 403 & 0.529 & 1.059 & 1.102 & 0.433 & 0.267 & 0.170 & 1.686 & 1.047 & 0.134 & 3.888 & 0.190 & 0.048 & 4.310 & 8.940 & 5.570 \\
\hline CIIILE & 48 & 0.310 & 0.921 & 1.073 & 0.343 & 0.224 & 0.103 & 1.776 & 1.264 & 0.104 & 5.604 & 0.458 & 0.382 & 8.724 & 10.999 & 8.239 \\
\hline CHINA & 76 & 0.547 & 0.486 & 0.730 & 0.536 & 0.553 & 0.055 & 1.321 & 0.968 & 0.138 & 3.887 & 4.801 & 0.983 & 8.274 & 7.586 & 6.584 \\
\hline COLOMBIA & 20 & 0.945 & 1.266 & 0.771 & 0.196 & 0.467 & 0.202 & 1.684 & 0.979 & 0.066 & 2.694 & 1.064 & 0.224 & 6.206 & 5.864 & 6.029 \\
\hline CZECH REP & 14 & NA & NA & NA & 0.398 & 0.234 & 0.157 & 1.950 & 1.117 & 0.162 & 3.139 & 0.958 & 0.333 & 5.433 & 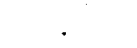 & . \\
\hline DENMARK & 121 & 0.516 & 1.520 & 1.794 & 0.601 & 0.325 & 0.163 & 1.756 & 1.087 & 0.232 & 4.574 & 0.510 & 0.256 & 4.153 & 12.040 & 6.825 \\
\hline FINLAND & 79 & 0.664 & 2.633 & 1.960 & 0.757 & 0.586 & 0.283 & 1.430 & 1.015 & 0.149 & 4.505 & 0.419 & 0.425 & 4.572 & 12.669 & 6.917 \\
\hline FRANCE & 428 & 0.597 & 1.278 & 1.467 & 0.631 & 0.478 & 0.203 & 1.417 & 0.986 & 0.172 & 3.390 & 0.928 & 0.360 & 2.553 & 9.2464 & 4.251 \\
\hline GERMANY & 414 & 1.020 & 1.212 & 1.278 & 0.609 & 0.371 & 0.130 & 1.756 & 1.026 & 0.229 & 3.175 & 0.982 & 0.189 & 1.509 & 8.814 & 3.499 \\
\hline GREECE & 94 & 0.455 & 1.216 & 0.788 & 0.325 & 0.166 & 0.008 & 1.516 & 1.086 & 0.176 & 4.702 & 3.083 & 0.186 & 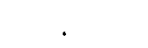 & . & . \\
\hline HONG KONG & 182 & 0.398 & 0.985 & 0.990 & 0.471 & 0.420 & 0.136 & 1.352 & 0.947 & 0.092 & 3.789 & 1.380 & 0.457 & 6.862 & 8.870 & 5.830 \\
\hline HUNGARY & 14 & 0.342 & 0.900 & 0.981 & 0.115 & 0.171 & 0.010 & 1.784 & 1.056 & 0.173 & 4.437 & 5.685 & 0.108 & . & . & . \\
\hline INDIA & 283 & 0.422 & 1.276 & 1.047 & 0.853 & 0.546 & 0.238 & 1.438 & 0.904 & 0.145 & 3.025 & 0.710 & 0.723 & 8.699 & 21.727 & 12.08 \\
\hline INDONESIA & 104 & 0.307 & 1.025 & 1.022 & 0.727 & 0.559 & 0.166 & 1.612 & 1.127 & 0.176 & 2.915 & 1.013 & 0.564 & 8.219 & 12.327 & 8.597 \\
\hline IRELAND & 46 & 0.320 & 1.881 & 1.084 & 0.517 & 0.281 & 0.170 & 1.576 & 1.143 & 0.185 & 4.420 & 0.274 & 0.186 & 5.396 & 13.554 & 6.603 \\
\hline ISRAEL & 28 & 0.386 & 0.879 & 1.007 & 0.416 & 0.296 & 0.093 & 1.813 & 1.165 & 0.234 & 5.189 & 0.912 & 0.298 & 4.865 & 6.685 & 4.555 \\
\hline ITALY & 125 & 0.812 & 0.499 & 0.977 & 0.619 & 0.718 & 0.223 & 1.454 & 1.096 & 0.170 & 2.891 & 1.405 & 0.256 & 2.269 & 5.659 & 3.179 \\
\hline
\end{tabular}




\begin{tabular}{|c|c|c|c|c|c|c|c|c|c|c|c|c|c|c|c|c|}
\hline JAPAN & 2116 & 0.357 & 1.926 & 1.372 & 0.707 & 0.432 & 0.157 & 1.319 & 1.025 & 0.138 & 3.594 & 1.201 & 0.241 & 1.182 & 3.675 & 2.005 \\
\hline KOREA (SOUTH) & 214 & 0.334 & 0.910 & 0.862 & 1.946 & 2.485 & 0.489 & 1.078 & 0.773 & 0.035 & 1.240 & 1.429 & 0.331 & 0.843 & 3.640 & 5.168 \\
\hline MALAYSIA & 253 & 0.388 & 0.916 & 1.072 & 0.464 & 0.144 & 0.038 & 1.296 & 0.913 & 0.086 & 6.773 & 2.351 & 0.127 & 9.256 & 14.306 & 8.571 \\
\hline MEXICO & 68 & 0.500 & 1.200 & 0.961 & 0.534 & 0.342 & 0.150 & 1.303 & 0.890 & 0.058 & 2.354 & 0.455 & 0.244 & 7.857 & 17.155 & 11.948 \\
\hline NETHERLANDS & 152 & 0.352 & 1.040 & 0.900 & 0.495 & 0.247 & 0.111 & 1.414 & 0.899 & 0.178 & 5.711 & 0.666 & 0.327 & 3.369 & 16.369 & 7.389 \\
\hline NEW ZEALAND & 37 & 0.195 & 0.943 & 0.531 & 0.535 & 0.265 & 0.189 & 1.504 & 0.925 & 0.062 & 6.652 & 0.111 & 0.124 & 7.611 & 14.439 & 9.499 \\
\hline NORWAY & 85 & 0.819 & 0.643 & 1.582 & 0.783 & 0.574 & 0.314 & 1.705 & 1.277 & 0.167 & 3.641 & 0.132 & 0.127 & 5.359 & 13.761 & 6.703 \\
\hline PAKISTAN & 72 & 0.382 & 1.284 & 1.123 & 1.134 & 0.999 & 0.244 & 0.993 & 0.510 & 0.012 & 1.795 & 1.909 & 0.036 & 2.306 & 9.366 & 8.103 \\
\hline PERU & 21 & 0.680 & 1.734 & 0.822 & 0.197 & 0.100 & 0.048 & 2.396 & 0.975 & 0.199 & 4.233 & 0.950 & 0.085 & 7.174 & 17.892 & 10.738 \\
\hline PHILIPPINES & 64 & 0.506 & 0.795 & 1.194 & 0.409 & 0.239 & 0.052 & 1.370 & 0.961 & 0.078 & 3.898 & 0.926 & 0.144 & 11.305 & 8.023 & 5.591 \\
\hline POLAND & 36 & 0.305 & 0.396 & 0.580 & 0.108 & 0.115 & 0.026 & 2.132 & 1.284 & 0.227 & 3.521 & 1.008 & 0.141 & 5.396 & 11.574 & 10.794 \\
\hline PORTUGAL & 53 & 0.872 & 1.429 & 1.090 & 0.667 & 0.591 & 0.222 & 1.220 & 0.837 & 0.048 & 2.108 & 1.057 & 0.090 & 2.390 & 5.050 & 4.215 \\
\hline SNGAPORE & 158 & 0.449 & 1.008 & 0.668 & 0.359 & 0.214 & 0.059 & 1.474 & 1.122 & 0.145 & 5.360 & 1.377 & 0.302 & 4.744 & 6.209 & 4.164 \\
\hline SOUTH AFRICA & 139 & 0.269 & 0.899 & 0.976 & 0.190 & 0.079 & 0.043 & 1.441 & 0.937 & 0.156 & 7.377 & 0.745 & 0.110 & 2.244 & 13.777 & 6.114 \\
\hline SPAIN & 97 & 0.771 & 1.571 & 0.910 & 0.317 & 0.293 & 0.103 & 1.302 & 0.951 & 0.123 & 3.053 & 1.676 & 0.185 & 3.114 & 9.809 & 5.154 \\
\hline SRI LANKA & 12 & 0.202 & 0.459 & 0.730 & 0.395 & 0.277 & 0.057 & 1.555 & 1.087 & 0.137 & 3.662 & 4.187 & 1.379 & 7.528 & 9.988 & 6.366 \\
\hline SWEDEN & 143 & 0.628 & 2.016 & 1.407 & 0.486 & 0.260 & 0.159 & 1.705 & 1.116 & 0.193 & 4.581 & 0.244 & 0.061 & 4.523 & 14.606 & 7.606 \\
\hline SWITZERLAND & 117 & 0.584 & 2.177 & 1.164 & 0.709 & 0.544 & 0.261 & 1.640 & 1.148 & 0.200 & 3.591 & 0.512 & 0.296 & 3.072 & 7.887 & 4.582 \\
\hline TAIWAN & 177 & 0.448 & 1.657 & 1.623 & 0.391 & 0.195 & 0.050 & 1.587 & 1.037 & 0.159 & 4.521 & 1.680 & 0.427 & 6.936 & 9.706 & 6.878 \\
\hline THAILAND & 190 & 0.435 & 1.002 & 0.979 & 1.046 & 0.915 & 0.220 & 1.143 & 0.697 & 0.047 & 2.675 & 1.464 & 0.193 & 5.180 & 9.400 & 6.827 \\
\hline TURKEY & 38 & 0.703 & 0.923 & 1.137 & 0.235 & 0.097 & 0.003 & 1.925 & 1.388 & 0.285 & 5.687 & 1.986 & 0.282 & 9.036 & 55.581 & 41.258 \\
\hline UK & 1124 & 0.363 & 1.178 & 1.022 & 0.374 & 0.182 & 0.068 & 1.370 & 0.921 & 0.146 & 5.950 & 0.740 & 0.125 & 4.079 & 13.804 & .7 .314 \\
\hline US & 2715 & 0.415 & 1.240 & 1.155 & 0.354 & 0.160 & 0.103 & $2.09 ?$ & 1.385 & 0.263 & 4.917 & 0.165 & 0.043 & 4.124 & 13.349 & 7.239 \\
\hline VENEZUELA & 11 & 1.002 & 0.962 & 1.173 & 0.351 & 0.411 & 0.141 & 1.559 & 0.964 & 0.112 & 2.464 & 0.756 & 0.760 & 8.263 & 18.086 & 16.048 \\
\hline
\end{tabular}


Table 5: Creditor Protection and Risks Measures

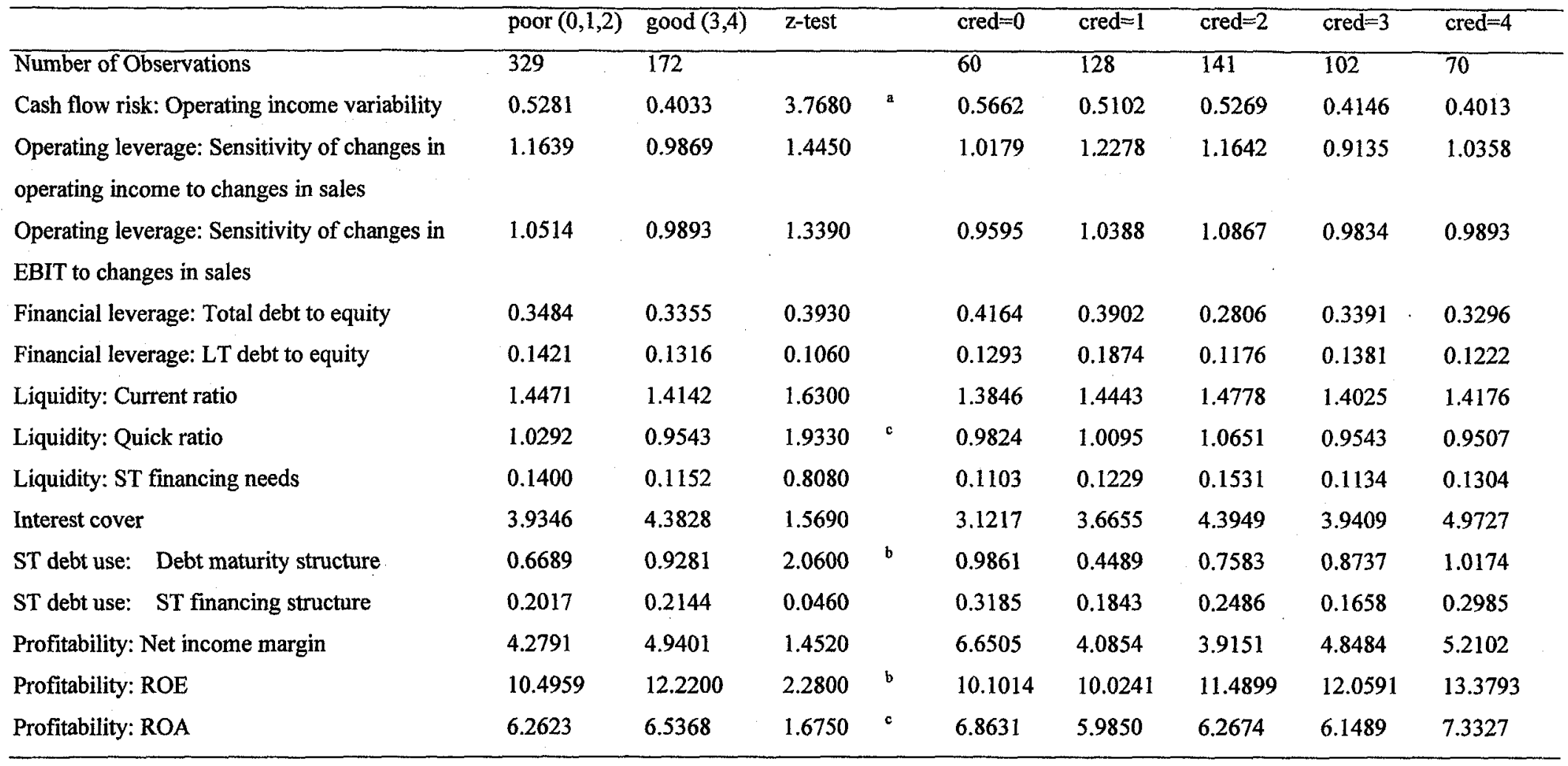

Note: Using a sample which excludes the G-7 countries leads to results which differ from those reported here for the two measures of financial leverage which are both statistically significant lower for poor creditor protection countries, and the short to long term debt ratio which is statistically significant higher for poor creditor protection countries.

${ }^{a}$ shows significance at the $1 \%$ level; ${ }^{b}$ shows significance at the $5 \%$ level; ${ }^{c}$ shows significance at the $10 \%$ level. 
Table 6: Shareholder Protection and Risks Measures

\begin{tabular}{|c|c|c|c|c|c|c|c|c|c|c|}
\hline & poor $(0-3)$ & Good $(4,5)$ & $z$-test & & Inv $=0$ & $\operatorname{Inv}=1$ & Inv $=2$ & Inv $=3$ & Inv $=4$ & Inv $=5$ \\
\hline Number of Observations & 306 & 202 & & & 12 & 54 & 112 & 128 & 107 & 95 \\
\hline Cash flow risk: Operating income variability & 0.5916 & 0.4035 & 5.6830 & a & 1.0633 & 0.8201 & 0.4399 & 0.5849 & 0.4296 & 0.3821 \\
\hline $\begin{array}{l}\text { Operating leverage: Sensitivity of changes in } \\
\text { operating income to changes in sales }\end{array}$ & 1.0555 & 1.1360 & 0.7730 & & 1.3670 & 0.9817 & 1.0583 & 1.1280 & 1.1991 & 1.0784 \\
\hline $\begin{array}{l}\text { Operating leverage: Sensitivity of changes in EBIT } \\
\text { to changes in sales }\end{array}$ & 1.0191 & 1.0163 & 0.1730 & & 0.4545 & 1.0626 & 0.9904 & 1.0990 & 1.0059 & 1.0163 \\
\hline Financial leverage: Total debt to equity & 0.4145 & 0.2878 & 4.1700 & $\mathrm{a}$ & 0.4215 & 0.5201 & 0.4162 & 0.3426 & 0.2899 & 0.2687 \\
\hline Financial leverage: LT debt to equity & 0.1509 & 0.1215 & 1.9970 & $b$ & 0.1733 & 0.1575 & 0.1637 & 0.1304 & 0.1231 & 0.1100 \\
\hline Liquidity: Current ratio & 1.4720 & 1.4039 & 1.2600 & & 1.3249 & 1.4317 & 1.5035 & 1.4742 & 1.3797 & 1.4209 \\
\hline Liquidity: Quick ratio & 1.0130 & 0.9873 & 0.6910 & & 0.8962 & 1.0133 & 0.9988 & 1.0225 & 1.0071 & 0.9756 \\
\hline Liquidity: ST financing needs & 0.1419 & 0.1152 & 1.2560 & & 0.1467 & 0.1155 & 0.1669 & 0.1364 & 0.1017 & 0.1344 \\
\hline Interest cover & 3.3020 & 4.8620 & 4.6890 & a & 4.0459 & 3.0458 & 3.3836 & 3.6054 & 5.2373 & 4.4888 \\
\hline ST debt use: Debt maturity structure & 0.8657 & 0.5852 & 4.1480 & a & 0.7892 & 1.0494 & 0.8766 & 0.8370 & 0.5802 & 0.5940 \\
\hline ST debt use: ST financing structure & 0.2842 & 0.1703 & 2.1460 & b & 0.4162 & 0.2488 & 0.2899 & 0.2744 & 0.1823 & 0.1547 \\
\hline Profitability: Net income margin & 4.4264 & 4.8280 & 1.4240 & & 2.2796 & 5.3920 & 4.4400 & 4.5072 & 4.7767 & 4.8280 \\
\hline Profitability: ROE & 10.1589 & 12.6891 & 2.7460 & a & 9.1521 & 9.8370 & 11.8390 & 8.9091 & 11.6722 & 13.5518 \\
\hline Profitability: ROA & 5.8064 & 6.9146 & 2.1270 & b & 4.1471 & 5.1457 & 6.6897 & 5.6976 & 6.3600 & 7.4575 \\
\hline
\end{tabular}

Note: Using a sample which excludes the G-7 countries leads to results which differ from those reported here for only one variable: the sensitivity of changes in operating income to changes in sales is statistically significant higher in poor investor protection countries.

${ }^{a}$ shows significance at the $1 \%$ level; ${ }^{b}$ shows significance at the $5 \%$ level. 
Table 7: Market vs. Bank-Centered Systems and Risk Measures

\begin{tabular}{|c|c|c|c|c|}
\hline & Market & Bank & z-test & \\
\hline Number of Observations & 232 & 276 & & \\
\hline Cash flow risk: Operating income variability & 0.4407 & 0.5352 & 2.9580 & a \\
\hline $\begin{array}{l}\text { Operating leverage: Sensitivity of changes in operating income to } \\
\text { changes in sales }\end{array}$ & 1.0502 & 1.1635 & 0.5630 & \\
\hline $\begin{array}{l}\text { Operating leverage: Sensitivity of changes in EBIT to changes in } \\
\text { sales }\end{array}$ & 1.0341 & 0.9975 & 0.1650 & \\
\hline Financial leverage: Total debt to equity & 0.2811 & 0.3919 & 3.0440 & a \\
\hline Financial leverage: LT debt to equity & 0.1255 & 0.1513 & 0.9330 & \\
\hline Liquidity: Current ratio & 1.4397 & 1.4418 & 0.5550 & \\
\hline Liquidity: Quick ratio & 0.9894 & 1.0120 & 0.3100 & \\
\hline Liquidity: ST financing needs & 0.1162 & 0.1345 & 0.9390 & \\
\hline Interest cover & 4.3078 & 3.6613 & 1.7390 & c \\
\hline ST debt use: Debt maturity structure & 0.6304 & 0.8759 & 3.0810 & a \\
\hline ST debt use: ST financing structure & 0.1776 & 0.2853 & 2.2720 & b \\
\hline Profitability: Net income margin & 4.8477 & 4.1387 & 1.8210 & c \\
\hline Profitability: $\mathrm{ROE}$ & 11.7499 & 10.2652 & 1.9630 & $\mathrm{~b}$ \\
\hline Profitability: ROA & 6.8993 & 5.6154 & 3.2500 & a \\
\hline
\end{tabular}

${ }^{a}$ shows significance at the $1 \%$ level; ${ }^{b}$ shows significance at the $5 \%$ level; ${ }^{c}$ shows significance at the $10 \%$ level. 
Table 8: Regression Analysis for Financial Leverage

(Total Debt over Book Value of Equity)

\begin{tabular}{|c|c|c|c|c|c|}
\hline Explanatory Variable & II & II & $\overline{\mathrm{I}}$ & $\overline{1}$ & \\
\hline Civil legal origin & $\begin{array}{r}14.6139 \\
(8.73)\end{array}$ & & & & $\begin{array}{r}27.3935 \\
(13.64)\end{array}$ \\
\hline Creditor rights & & $\begin{array}{r}-1.2314 \\
(1.99)\end{array}$ & & & \\
\hline Antidirector rights & & & $\begin{array}{r}-7.0608 \\
(11.90)\end{array}$ & & \\
\hline Bank oriented system & & & & $\begin{array}{r}-8.7917 \\
(4.42)\end{array}$ & $\begin{array}{r}-26.9952 \\
(11.34)\end{array}$ \\
\hline Availability of collateral & $\begin{array}{r}68.5494 \\
(15.50)\end{array}$ & $\begin{array}{r}65.1762 \\
(14.66)\end{array}$ & $\begin{array}{r}67.2011 \\
(15.33)\end{array}$ & $\begin{array}{r}61.6066 \\
(13.87)\end{array}$ & $\begin{array}{r}64.9137 \\
(14.75)\end{array}$ \\
\hline Non-debt tax shield & $\begin{array}{r}-93.4694 \\
(12.72)\end{array}$ & $\begin{array}{r}-82.4859 \\
(11.29)\end{array}$ & $\begin{array}{r}-95.3417 \\
(13.09)\end{array}$ & $\begin{array}{r}-75.3499 \\
(10.27)\end{array}$ & $\begin{array}{r}-87.3396 \\
(11.94)\end{array}$ \\
\hline Operating income as a share of total assets & $\begin{array}{r}-168.6183 \\
(12.63)\end{array}$ & $\begin{array}{r}-204.3292 \\
(15.98)\end{array}$ & $\begin{array}{r}-156.8320 \\
(11.81)\end{array}$ & $\begin{array}{r}-215.7974 \\
(16.55)\end{array}$ & $\begin{array}{r}-174.2200 \\
(13.14)\end{array}$ \\
\hline Market capitalization & $\begin{array}{r}-2.0944 \\
(3.80)\end{array}$ & $\begin{array}{r}-2.6947 \\
(4.84)\end{array}$ & $\begin{array}{r}-2.4203 \\
(4.42)\end{array}$ & $\begin{array}{r}-3.0487 \\
(5.42)\end{array}$ & $\begin{array}{r}-3.2421 \\
(5.82)\end{array}$ \\
\hline Total asset growth & $\begin{array}{r}38.2347 \\
(7.24)\end{array}$ & $\begin{array}{r}36.6947 \\
(6.89)\end{array}$ & $\begin{array}{r}35.2610 \\
(6.70)\end{array}$ & $\begin{array}{r}36.1811 \\
(6.83)\end{array}$ & $\begin{array}{r}35.8294 \\
(6.83)\end{array}$ \\
\hline Volatility of earnings & $\begin{array}{r}7.0112 \\
(9.10)\end{array}$ & $\begin{array}{r}5.6057 \\
(7.35)\end{array}$ & $\begin{array}{r}7.1686 \\
(9.39)\end{array}$ & $\begin{array}{r}5.3432 \\
(6.98)\end{array}$ & $\begin{array}{r}6.7895 \\
(8.87)\end{array}$ \\
\hline Tax advantage of debt & $\begin{array}{r}0.0741 \\
(24.81)\end{array}$ & $\begin{array}{c}0.0852 \\
(31.15)\end{array}$ & $\begin{array}{r}0.0844 \\
(31.21)\end{array}$ & $\begin{array}{r}0.0953 \\
(26.50)\end{array}$ & $\begin{array}{r}0.0964 \\
(27.09)\end{array}$ \\
\hline GNP per capita & $\begin{array}{r}-1.4637 \\
(1.74)\end{array}$ & $\begin{array}{r}-1.6927 \\
(1.97)\end{array}$ & $\begin{array}{r}-0.7852 \\
(0.94)\end{array}$ & $\begin{array}{r}-1.7885 \\
(2.11)\end{array}$ & $\begin{array}{r}-2.9059 \\
(3.44)\end{array}$ \\
\hline Industry dummies & Yes & Yes & Yes & Yes & Yes \\
\hline Number of Observations & 9016 & 9008 & 9016 & 9016 & 9016 \\
\hline Overall $R^{2}$ & 0.1677 & 0.1612 & 0.1737 & 0.1625 & 0.1794 \\
\hline
\end{tabular}

Notes: OLS regressions with industry fixed effects. The dependent variable is total debt over book value of common equity. The independent variables are: (1) civil legal origin dummy that equals one if the country is of civil legal origin; (2) creditor rights index, ranging from 0 to 4 , where higher values signify stronger creditor protection; (3) anti-director rights index, ranging from 0 to 5 , where higher values signify stronger minority shareholder protection; or (4) bank-market indicator that equals one if the country's financial system is bank-based. The control variables are (5) availability of collateral, (6) non-debt tax shields; (7) operating income as a share of total assets; (8) company market capitalization; (9) total asset growth; (10) volatility of earnings; (11) tax advantage of debt; (12) GNP per capita. For definitions of variables see Table 2. Observations are capped at the $10 \%$ level (both tails). 
Table 9: Regression Analysis

\begin{tabular}{|c|c|c|c|c|c|c|}
\hline Dependent variable & Explanatory Variables & $\bar{I}$ & II & III & IV & $\bar{V}$ \\
\hline Cash flow risk: Operating income variability & civil legal origin & + & & & & + \\
\hline & antidirector rights & & & - & & \\
\hline Operating leverage: Sensitivity of EBIT to changes in sales & civil legal origin & + & & & & 0 \\
\hline & creditor rights & & 0 & & & \\
\hline & antidirector rights & & & - & & \\
\hline . & bank oriented system & & & & + & 0 \\
\hline & antidirector rights & & & - & & \\
\hline & bank oriented system & & & & + & 0 \\
\hline ST debt use: Debt maturity structure & civil legal origin & + & & & & + \\
\hline & creditor rights & & + & & & \\
\hline & antidirector rights & & & - & & \\
\hline & bank oriented system & & & & + & + \\
\hline Liquidity: Current ratio & civil legal origin & - & & & & - \\
\hline & creditor rights & & + & & & \\
\hline & antidirector rights & & & + & & \\
\hline & bank oriented system & & & & - & + \\
\hline Net income margin & civil legal origin & - & & & & - \\
\hline & creditor rights & & + & & & \\
\hline & antidirector rights & & & + & & \\
\hline & bank oriented system & & & & - & - \\
\hline
\end{tabular}

Notes: Summary regression results. Signs of coefficients are reported of those are statistically significant, positive $(+)$ or negative $(-) ; 0$ otherwise. OLS regressions with industry fixed effects. The dependent variables are (1) operating income variability, (2) sensitivity of EBIT to changes in sales, (3) total debt to market value of common equity, (4) the current ratio, (5) interest coverage, and (6) net income margin. The independent variables are as in Table 8. The control set for total debt to market value of equity are as in Table 8. The contro set for all other regressions is composed of market capitalization; total asset growth; GNP per capita. For definitions of variables see Tabl 2. Observations are capped at the $10 \%$ level (both tails). 
${ }^{1}$ World Bank, World Bank and CEPR, and Harvard University. We thank Ying Lin for excellent research support, Richard Lyons and participants in the conference on Financial Crises in Emerging Markets, organized by the Federal Reserve Bank of San Francisco, seminar participants at Harvard University and George Washington University, Reuven Glick, Oliver Hart, Rafael La Porta, Randall Morck, Ramon Moreno, Andrei Shleifer, and the three reviewers for helpful comments. ^ Corresponding author: tel. 2024737212 ; EM: Cclaessens@worldbank.org.

${ }^{2}$ See Demirgüç-Kunt and Maksimovic (1998 and forthcoming) on financing patterns and growth, and La Porta et al. (1999b) for a survey on legal and institutional environments and their impact on the corporate sector.

${ }^{3}$ Krugman (1999) draws attention to the possibility of a "transfer problem" arising if the corporate sector has large foreign exchange liabilities.

${ }^{4}$ There has been extensive theoretical and empirical literature building on the Krugman (1979) model, e.g. Edwards and Santaella (1993), Eichengreen, Rose and Wyplosz (1995), and Chang and Velasco (1998). The moral hazard view is theoretically and empirically explored by Akerlof and Romer (1993), and Corsetti, Pesenti, and Roubini (1998).

${ }^{5}$ Based on the Diamond and Dybvig (1983) bank run model and the Obstfeld (1994) second generation balance of payments model, Radelet and Sachs (1998) defend the view that in macro-economic and otherwise sound countries a crisis can be provoked by a selffulfilling panic.

${ }^{6}$ For one, predicting financial crises is a risky business, with mixed explanatory powers (especially when considering Type I versus Type II errors, see further Portes 1999 for a 
critical review of crisis prediction models). Furthermore, there are few theoretical models on the importance of corporate sector financing patterns and the risk of a financial crisis. In addition, systemic risks arising from the corporate sector likely are due not only to risky financial structures of individual corporations but also to the interaction among corporations and between the corporate sector, financial sector and the rest of the economy. A robust analysis requires a well-specified model to investigate the role of the corporate sector in contributing to a financial crisis while avoiding the risks of an ex-post data-mining exercise to find weaknesses which can "explain" the occurrence of crises. This becomes important as financing patterns often do not change much over short periods of time. Related work suggests that there were no obvious changes in measures of East Asian corporations' performance or financing patterns in the period before crisis. The classification of countries as crisis or non-crisis is not free of subjective judgment either. There are, for example, many countries with a systemic, long-drawn crisis which do not suffer from a financial crisis involving a currency collapse or open banking crisis. In general, the relationships between countries' financial crises and their corporate sector financing structures and performance is complex and requires rigorous modeling before any empirical conclusions are made.

${ }^{7}$ Roman law was compiled under the direction of Byzantine Emperor Justinian in the sixth century. Over subsequent centuries, the law was interpreted and adapted to confront problems as they arose throughout Europe. Eventually, individual countries formalized individual legal codes. The French Civil Code was written in 1804 under the direction of Napoleon. He had the Code adopted in all conquered territories, including Italy, Poland, the low countries, and the Habsburg Empire. Through conquest and colonization, France extended her legal influence to parts of the Near East, Northern and 
Sub-Saharan Africa, Indochina, Oceania, French Guiana, and the French Caribbean islands during the colonial era. Furthermore, since the French Civil Code exerted a major influence on the Portuguese and Spanish legal systems, this helped spread the French legal tradition to Central and South America. Following the unification of Germany under Bismarck in 1871, the German Civil Code was completed in 1896. The German Code exerted a big influence on Austria and Switzerland, as well as China, Czechoslovakia, Greece, Hungary, Italy, and Yugoslavia. Also, the German Civil Code heavily influenced the Japanese Civil Code, which helped spread the German legal tradition to Korea. The Scandinavian countries developed their Civil Codes in the $17^{\text {th }}$ and $18^{\text {th }}$ centuries. These countries have remained relatively unaffected by the farreaching influences of the English, German and French legal traditions.

The common law tradition, prevalent in countries formerly part of the British Empire, is not characterized by laws that are heavily shaped by legal scholars. Instead, laws are influenced by judges trying to resolve particular cases.

${ }^{8}$ In this context, the effect of investor rights protection on leverage is more complex, since higher leverage does not always signify higher risk. Higher debt, for example, may be optimal in a company with more stable cash flows, holding other factors constant. The relation between investor rights and leverage thus needs to be isolated by controlling for all company specific leverage determinants, as per the Modigliani-Miller framework for example stability of the income stream and type of industry. After proper controls, however, we can conclude that higher than optimal leverage increases overall corporate risk, thus reducing corporate value to both creditors and shareholders. We would thus hypothesize that, all other factors constant, better investor rights protection is associated with lower leverage at the optimum. 
9 Demirguc-Kunt and Levine (1999) explore whether fundamental differences can explain why some countries are characterized as bank-based and others as market-based. They find that countries with common law tradition and strong investor rights tend to be more market-based, and civil law countries more bank-based. The fact that legal systems help in the taxonomy of financial systems does not resolve the issue of causality as political economy might well result in the adoption of legal and other institutional features which are consistent with either system, see Rajan and Zingales (1999).

${ }^{10}$ Specifically, the sensitivity of changes in operating income and EBIT to sales, the variability of operating income, and EBIT, and a measure for firm growth, the total assets growth rate.

${ }^{11}$ We control for country and industry differences in distribution by splitting the sample firms into 522 groups, which we form using all 12 industry groups in our 46 countries. We then take the median of each group, and use the medians as observations whose distributions we compare. This methodology has the advantage that cross-country differences in firm size are not a concern, since medians have no obvious size bias. This a median firm in the US may be smaller or larger than a median firm in a developing country.

12 We repeat the z-tests under the assumption of a common distribution (where the distribution is allowed to vary only along the two groups being compared in the z-test), and obtain results consistent with the ones reported here, only much stronger.

${ }^{13}$ In addition to the impact of the firm-specific characteristics that we control for, it is important to note that corporate risk may be affected by industry group affiliation of the company. In particular, it is possible that in countries where industrial groupings are common, there exists an intra-group risk-sharing mechanism. Such intra-group risk 
sharing will result in high measured company-level risk, even though risk on the group level is consistent with optimal behavior.

14 The sectors are defined as follows: Petroleum industry (SIC 13 and 29); Finance and Real Estate (SIC 60-69); Consumer Durables (SIC 25, 30, 36, 37, 50, 55, and 57); Basic Industry (SIC 10, 12, 14, 24, 26, 28, 33); Food and Tobacco (SIC 1, 20, 21, 54); Construction (SIC 15-17, 32, 52); Capital Goods (SIC 34, 35, and 38); Transportation (SIC 40-42, 44, 45, and 47); Utilities (SIC 46, 48, and 49); Textiles and Trade (SIC 2223, 31, 51, 53, 56, 59); Services (SIC 72-73, 75, 80, 82, 89); and Leisure (SIC 27, 58, 70, 78-79). We add a $12^{\text {th }}$ category - "other services", which includes SIC codes $43,76,83$, $84,86,87,92,95,96,99$.

${ }^{15}$ For example, according to standard convergence arguments, countries at a lower level of development grow faster. Therefore, the corporate sectors in such countries may be justified to pursue riskier financing and operating policies given the higher rates of return to investments in a faster-growing economy. That will introduce a bias since economies at a lower level of development also happen to be predominantly of civil legal origin. We control for this bias by including initial GNP per capita as a control variable.

${ }^{16}$ We argue that the optimal leverage would decrease in the volatility of a company's earnings, as management minimizes the probability of earnings falling below interest expenses; however, Titman and Wessels (1988) point out to counter-arguments to the above.

${ }^{17}$ We control for the debt tax advantage using the classical formula for the gain from leverage from Miller 1977: $\left[1-\frac{\left(1-\tau_{C}\right)\left(1-\tau_{S}\right)}{\left(1-\tau_{B}\right)}\right] D$, where $\tau_{C}$ is the corporate tax rate, $\tau_{S}$ is the tax rate applicable to income form stock (specifically - dividend tax), $\tau_{\mathrm{B}}$ is the tax 
rate applicable to income from bonds (specifically - interest tax rate), and D is the value of outstanding firm debt (in US\$, logs). Alternatively, some authors use the personal tax rate as the rate applicable to income from bonds, and use the capital gains tax as the rate applicable to income from stock. Our analysis is unaffected by using these alternative measures. The tax data are on withholding tax rates in 1996, and are collected by PriceWaterhouse.

18 A random industry effects specification (not reported) leads to virtually the same results.

${ }^{19}$ We repeat all regressions using the 522 country-industry group medians, instead of all 11033 observations, to obtain results that are directly comparable to the z-tests above. The results are broadly consistent with those reported in tables 8 and 9. The differences are as follows. The operating leverage and liquidity regressions show that relationship between those two variables and country regulatory frameworks are not robust as none of the coefficients are significant. The relationship between the regulatory framework and cash flow risk, financial leverage, and interest coverage are robust to this more stringent regression specification. Debt maturity structure regressions show that short-term debt usage is only related to creditor rights protection in a robust way. Net income margin regressions maintain the significance of the relationship of profitability to the country legal origin and to shareholder rights, but not to creditor rights. In all regressions, the nature of the financial system - whether it is bank- or market-based - has weak explanatory power over and above the regulatory framework in the country.

${ }^{20}$ Results are similar when we control in addition for the relative degree of enforcement of creditor and shareholder protection in each country, using an index of judicial efficiency. 
${ }^{21}$ Demirguc-Kunt and Maksimovic (forthcoming)

${ }^{22}$ An alternative measure that reflects the effectiveness of the country regulatory framework is the quality of accounting standards and the transparency of corporate financial statements reporting. Accounting standards may further be an important factor to control for, since our risk measures are based on accounting data, as opposed to financial market-based figures. Thus one could envision that differences in reporting standards would impact our risk measures in a country-specific, systematic manner, thus necessitating a control for reporting-induced bias. We check the impact of accounting standards as a robustness check to our regression results, using the accounting standards variable constructed by La Porta et al. (1998). The results are maintained as reported above. In addition, the quality of corporate reporting have the expected impact on corporate risk. Specifically, better and more transparent reporting is negatively associated with cash-flow risk, financial leverage, and liquidity, and positively associated with interest coverage and profitability. There is no significant relationship between accounting standards quality and operating leverage or the debt maturity structure. 





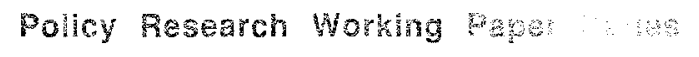

\section{Thite}

WPS2252 Productivity Growth, Capital Accumulation, and the Banking

Sector: Some Lessons from Malaysia

WPS2253 Revenue Recycling and the Welfare Effects of Road Pricing

WPS2254 Does "Grease Money" Speed Up the Wheels of Commerce?

WPS2255 Risk and Efficiency in East Asian Banks

WPS2256 Geographical Disadvantage: A Heckscher-Ohlin-von Thunen Model of International Specialization

WPS2257 Infrastructure, Geographical Disadvantage, and Transport Costs

WPS2258 Market Access Bargaining in the Uruguay Round: Rigid or Relaxed Reciprocity?

WPS2259 Predicting Currency Fluctuations and Crises: Do Resident Firms Have an Informational Advantage?

WPS2260 Regional Integration Agreements: A Force for Convergence or Divergence?

WPS2261 Is Knowledge Shared within Households?

WPS2262 How Inadequate Provision of Public Infrastructure and Services Affects Private Investment

WPS2263 When is Growth Pro-Poor? Evidence from the Diverse Experiences of India's States

WPS2264 Do More Unequal Countries Redistribute More? Does the Median Voter Hypothesis Hold?
Author

Ejaz Ghani

Vivek Suri

Ian W. H. Parry

Antonio Miguel R. Bento

Daniel Kaufmann

Shang-Jin Wei

Luc Laeven

Anthony J. Venables

Nuno Limão

Nuno Limão

Anthony J. Venables

J. Michael Finger

Ulrich Reincke

Adriana Castro

Daniel Kaufmann

Gil Mehrez

Sergio Schmukler

Anthony J. Venables

Kaushik Basu

Ambar Narayan

Martin Ravallion

Ritva Reinikka Jakob Svensson

Martin Ravallion

Gaurav Datt

Branko Milanovic
Desember 1999

December 1999

December 1999

December 1999

December 1999

L. Tabada 36896

Contact for paper

N. Mensah 80546

R. Yazigi 37176

H. Sladovich 37698

R. Vo

33722

L. Tabada 36896

December 1999

December 1999

L. Tabada 36896

December 1999

E. Khine 37471

December 1999

M. Mason 30809

December 1999

H. Sladovich 37698

December 1999

J. Israel 85117

December 1999

P. Sader 33902 


\section{Policy Research Working Paper Series}

Title

WPS2265 The Political Economy of Distress

in East Asian Financial Institutions

WPS2266 The Impact of Adult Deaths on Children's Health in Northwestern Tanzania

WPS2267 Do High Interest Rates Defend Currencies during Speculative Attacks?

WPS2268 The Structure of Social Disparities In Education: Gender and Wealth

WPS2269 Context is Everything: Measuring Institutional Change in Transition Economies

WPS2270 The Optimal Income Tax When Poverty !s a Public "Bad"
Author

Paola Bongini

Stijn Claessens

Giovanni Ferri

Martha Ainsworth

Innocent Semali

Aart Kraay

Deon Filmer

Nauro F. Campos

Waly Wane
Date

January 2000

January 2000

January 2000

January 2000

January 2000

January 2000
Contact for paper

R. Vo

33722

S. Fallon 38009

R. Bonfield 31248

S. Fallon 38009

J. Victor 36549

H. Sladovich 37698 